\title{
Temporal responses of protein synthesis in human skeletal muscle to feeding
}

\author{
BY M. A. MCNURLAN ${ }^{1}$, P. ESSEN ${ }^{2}$, E. MILNE ${ }^{1}$, E. VINNARS ${ }^{3}$, P. J. GARLICK ${ }^{1}$ \\ AND J.WERNERMAN ${ }^{3}$ \\ ${ }^{1}$ The Rowett Research Institute, Bucksburn, Aberdeen AB2 9SB \\ Department of Anesthesiology and Intensive Care at ${ }^{2}$ Huddinge University Hospital and \\ ${ }^{3}$ St Görans Hospital, Stockholm, Sweden
}

(Received 19 July 1991-Accepted 12 March 1992)

\begin{abstract}
In attempting to evaluate alterations in metabolic responses to dietary nutrients that occur in pathological conditions in man, it is first necessary to understand normal metabolic responses. The present study set out to determine the temporal responses of protein synthesis in the skeletal muscle of healthy subjects to the consumption of food. Sequential measurements of protein synthesis in quadriceps muscle were made in eight subjects by injection of $0.05 \mathrm{~g} \mathrm{~L}-\left[1-{ }^{13} \mathrm{C}\right]$ leucine $/ \mathrm{kg}$ body-weight. The rate of protein synthesis after an overnight fast (i.e. in the post-absorptive state) was $2.2 \%$ muscle protein. After $1 \mathrm{~h}$ of eating, protein synthesis was unaltered $(2 \cdot 2 \% / \mathrm{d})$, but after $10 \mathrm{~h}$ of consuming small hourly meals the rate had risen to $2.9 \% / \mathrm{d}$, with a variation in response among individuals. The response of muscle to $10 \mathrm{~h}$ of feeding was also investigated in subjects who underwent only one measurement each, either after $10 \mathrm{~h}$ of eating small meals or after the same time-period when no food was given. Protein synthesis rates were only slightly elevated in the group of fed individuals $(2.3 \% / \mathrm{d}, n \boldsymbol{6})$ compared with the fasted group $(2.1 \% / d, n 6)$. Taken together the two studies suggest that in healthy adults muscle protein synthesis does not respond quickly to the influx of dietary nutrients and that even after $10 \mathrm{~h}$ of feeding any stimulation of protein synthesis is small.
\end{abstract}

Protein synthesis: Human skeletal muscle: Response to feeding

The response of protein metabolism to dietary intake in adult man is not clear. Measurements of whole-body protein metabolism assessed from the disappearance of labelled leucine from plasma have given rise to differing conclusions. Studies by Rennie et al. (1982), Hoffer et al. (1985) and Conway et al. (1988) have suggested that the rate of protein synthesis was increased in the fed state compared with fasting values. However, a range of other studies with essentially the same methodology have reported no stimulation in whole-body protein synthesis with feeding, but instead, a large decrease in whole-body protein degradation (e.g. Motil et al. 1981 a, b; Young et al. 1987; Melville et al. 1989; Bruce et al. 1990).

Although these findings on whole-body protein turnover are somewhat unclear, the responses of individual tissues which can be measured directly, such as muscle, should be more conclusive, as the measurement of protein synthesis can be made directly from incorporation of a labelled amino acid. An investigation carried out by Rennie et al. (1982) with leucine labelled with ${ }^{13} \mathrm{C}$ has demonstrated substantial increases in muscle protein synthesis in healthy individuals who were fed compared with individuals in the postabsorptive state. Although some questions of methodology have arisen over this study, an increase of $60 \%$ in muscle protein synthesis has been confirmed in a subsequent report 
(Halliday et al. 1988) for a group of individuals fed for $10 \mathrm{~h}$ compared with a group who continued fasting.

The aim of the present study was to investigate the responses of protein metabolism to feeding with a different method for assessing protein synthesis. Rather than using a continuous infusion of a tracer amount of $\mathrm{L}-\left[{ }^{13} \mathrm{C}\right]$ leucine, a method was employed in which a large amount (about $4 \mathrm{~g}$ ) of labelled leucine was given. The advantages of this approach have been presented in detail elsewhere (Garlick et al. 1989) but the principle behind this procedure is to minimize uncertainty over the labelling in the precursor amino acid for protein synthesis. One of the advantages of this flooding procedure is that measurements can be completed over $90 \mathrm{~min}$. It was, therefore, possible to examine the rapidity with which muscle tissue responds to nutrient intake. A preliminary report of the present study has been presented (McNurlan et al. 1990).

\section{METHODS \\ Subjects and protocols}

The present study was conducted as two experiments. In Expt 1 three sequential measurements of muscle protein synthesis rates were made in a group of eight healthy individuals, age 27 (SD 3) years, height 1.84 (SD 0.06) m, weight 74 (SD 9) kg, body mass index (BMI; weight $/$ height $^{2}$ ) 22 (SD 2). The first measurement was made after an overnight fast. When the measurement was completed the subjects began a regimen of twelve standard meals consisting of milk, bread, butter and cheese which were consumed each hour. Since the present study was designed to provide information which would aid in the interpretation of clinical studies, the level of oral intake was comparable with that normally provided to patients receiving total parenteral nutrition. The dietary intake provided $10 \mathrm{~g}$ protein and $1308 \mathrm{KJ}(250 \mathrm{kcal}) / \mathrm{h}$.

In Expt 2, separate groups of six individuals were measured in the fasted state: age 28 (SD 5) years, height 181 (SD 0.09) $\mathrm{m}$, weight 73 (SD 10) kg; BMI 21 (SD 1) or in the fed state: age 29 (SD 7) years, height 1.85 (SD 0.04) $\mathrm{m}$, weight 73.5 (SD 5) $\mathrm{kg}$, BMI 21 (SD 1). The measurements were started $10 \mathrm{~h}$ after the fed group had begun their hourly meals. During this $10 \mathrm{~h}$ the fasted group continued their overnight fast.

Both experiments were approved by the Ethical Committee of the Karolinska Institute, Stockholm.

\section{Measurement of muscle protein synthesis}

The procedure for the measurement of muscle protein synthesis rates employing the flooding technique was the same for Expts 1 and 2 and has been described in detail previously (Garlick et al. 1989).

L- $\left[1^{13} \mathrm{C}\right]$ leucine (Tracer Technologies, Somerville, MA, USA), verified for the absence of D-isomers and heat sterilized, was injected intravenously as a $20 \mathrm{~g} / 1$ solution in saline $(9 \mathrm{~g} \mathrm{NaCl} / 1)$ at $0.05 \mathrm{~g} / \mathrm{kg}$ body weight and 20 atoms $\%$ enrichment. Arterial blood samples in Expt 1 and venous blood samples in Expt $2(10 \mathrm{ml})$ were taken into heparinized tubes at $0,5,10,15,30,60$ and $90 \mathrm{~min}$ for the determination of free leucine enrichment. The enrichments of leucine and $\alpha$-ketoisocaproate ( $\mathrm{KIC}$; the keto acid of leucine) were measured by gas-liquid chromatography-mass spectrometry on a VG 12-250 quadrupole mass spectrometer (VG Masslab, Manchester). Leucine was measured as the tertiary butyldimethylsilyl derivative and KIC was measured as the quinoxoxalinoltertiarybutyldimethylsilyl derivative under electron impact and selective ion monitoring as described by Calder \& Smith (1988).

Incorporation of labelled leucine into protein over the period of measurement was 
determined from percutaneous biopsies of quadriceps muscle taken at 0 and $90 \mathrm{~min}$. Biopsies were frozen in liquid $\mathrm{N}_{2}$ and stored at $-20^{\circ}$ until analysis. At the time of analysis, muscle samples were pulverized between aluminium blocks cooled with solid $\mathrm{CO}_{2}$ and precipitated with $0.2 \mathrm{~mol}$ perchloric acid (PCA)/l. After centrifugation the supernatant fraction was neutralized with $10 \mathrm{~mol} / 1 \mathrm{KOH}$ and used to determine the enrichment of free leucine in the tissue. Enrichment was measured by gas-liquid chromatography-mass spectrometry on the VG 12-250, described previously, using the $N$-heptafluorobutyryl $n$ butyl ester derivative under negative chemical ionization (Mackenzie \& Tenaschuk, 1974; Ford et al. 1985). The protein pellet from PCA precipitation was extensively washed, solubilized in $0.3 \mathrm{~mol} \mathrm{NaOH} / 1$ reprecipitated with PCA and hydrolysed in concentrated $\mathrm{HCl}$ for $24 \mathrm{~h}$. $\mathrm{HCl}$ was removed by evaporation and leucine was separated by ion-exchange chromatography on a $600 \times 9 \mathrm{~mm}$ column. The column eluate containing leucine in $0.2 \mathrm{~mol}$ citrate $/ 1$ was put through a small $(50 \times 9 \mathrm{~mm})$ ion-exchange column and eluted with $4 \mathrm{~mol} \mathrm{NH}_{4} \mathrm{OH} / 1$. Following removal of the $\mathrm{NH}_{4} \mathrm{OH}$, samples containing $3 \mu \mathrm{mol}$ amino acid were decarboxylated with ninhydrin in sealed tubes essentially as described by Read et al. (1984). The enrichment of ${ }^{13} \mathrm{CO}_{2}$ was determined on a gas isotope mass spectrometer (SIRA 12; VG Isogas, Middlewich, Chester).

All measurements of enrichment were made in comparison with appropriately labelled standards.

\section{Plasma glucose and hormone levels}

Plasma glucose was determined using a glucose dehydrogenase (EC 1.1.1.47) method (Banauch et al. 1975). Radioimmunoassay was used to determine the plasma concentrations of insulin (Midgley et al. 1969), glucagon (Eisentraut et al. 1968) and cortisol (Dash et al. 1975).

\section{Calculations and statistics}

The calculation of the rate of protein synthesis was similar to that described previously by McNurlan et al. (1979), employing the equation:

$$
k_{s}=\left(P_{(t)}-P_{(0)}\right) \times 100 / A,
$$

where $k_{s}$ is the fraction of the protein pool synthesized each day, $P_{(t)}-P_{(0)}$ represents the increase in enrichment of leucine in protein from the beginning $\left(P_{(0)}\right)$ to the end $\left(P_{(t)}\right)$ of the experiment and $A$ is the area inscribed by the precursor enrichment and the time. Precursor enrichment was assumed to be best represented by the enrichment of plasma $\alpha$ ketoisocaproate from seven sequential measurements (see p. 122).

The values are expressed as mean values with their standard errors. The statistical evaluation of the data was made by two-tailed $t$ tests, for paired observations in Expt 1 and unpaired observations in Expt 2. Although there was no obvious deviation from normal distribution, the data have also been analysed with the non-parametric tests, Wilcoxon's two-tailed signed rank test (for paired evaluations) and Mann-Whitney U (for non-paired evaluations), because of the rather small number of observations $(n 6-8)$ involved.

\section{RESULTS}

The results of Expt 1 (Table 1) show that after an overnight fast the rate of protein synthesis in quadriceps muscle was $2.2 \%$ of the muscle protein per $\mathrm{d}$, with a range of values from $1.43 \% / \mathrm{d}$ to $3.2 \% / \mathrm{d}$. The rate did not respond rapidly to the onset of feeding. The measurement made during the $90 \mathrm{~min}$ period beginning $1 \mathrm{~h}$ after the first of the hourly meals indicated rates of protein synthesis that were very similar to those in the postabsorptive state. During the third measurement of protein synthesis, started $10 \mathrm{~h}$ after the 
Table 1. Expt 1. Rates of protein synthesis $\left(\mathrm{k}_{\mathrm{s}} ; \% / d\right)$ in quadriceps muscle from healthy subjects in the post-absorptive state, $1 \mathrm{~h}$ and $10 \mathrm{~h}$ after eating*

\begin{tabular}{ccccc}
\hline \hline Subject no. & Post-absorptive $1 \mathrm{~h}$ fed & $10 \mathrm{~h}$ fed & $=$ \\
1 & 2.37 & 1.83 & 3.59 \\
2 & 3.21 & 2.74 & 3.20 \\
3 & 1.75 & 1.56 & - \\
4 & 2.95 & 2.15 & 2.98 \\
5 & - & 2.94 & 3.14 \\
6 & 1.80 & 2.45 & 3.75 \\
7 & 1.97 & 2.10 & 2.60 \\
8 & 1.43 & 1.48 & 1.05 \\
Mean & 2.21 & 2.15 & 2.90 \\
SEM & 0.25 & 0.19 & 0.34 \\
\hline
\end{tabular}

* For details of subjects and procedures, see pp. 118-119.

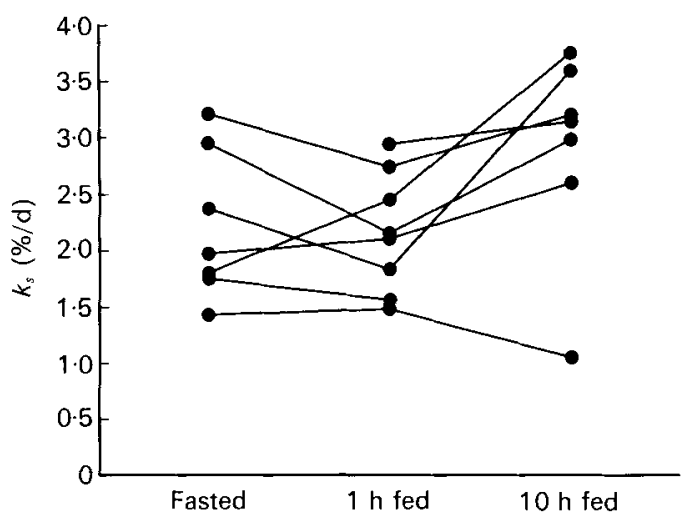

Fig. 1. Expt 1. The rate of protein synthesis in quadriceps muscle of healthy subjects measured with $0.05 \mathrm{~g}$ $\mathrm{L}-\left[1-{ }^{13} \mathrm{C}\right]$ leucine $/ \mathrm{kg}$ in the post-absorptive state, after $1 \mathrm{~h}$ of feeding and after $10 \mathrm{~h}$ of feeding. For details of subjects and procedures, see pp. 118-119.

first meal, an elevation of approximately $30 \%$ was apparent. Statistical evaluation of the data with either a paired $t$ test or the non-parametric, Wilcoxon's two-tailed signed rank test indicates that the values at $10 \mathrm{~h}$ are not significantly different from the post-absorptive values $(P>0.05)$. The difference between the values at $1 \mathrm{~h}$ and those at $10 \mathrm{~h}$ is, however, significant $(P=0.05)$. The data have also been examined by calculating the mean of the post-absorptive value and the value at $1 \mathrm{~h}$ and assessing the difference between this mean value and the value at $10 \mathrm{~h}$. This difference is also not statistically significant $(\mathrm{P}>0.05)$. In addition, the data can be examined on an individual basis (Fig. 1), when it is apparent that four individuals did not increase muscle protein synthesis even after $10 \mathrm{~h}$ of feeding. One individual had a moderate increase in synthesis rate and in two individuals the rate of muscle protein synthesis was substantially increased after $10 \mathrm{~h}$ of eating.

By the first hour after eating began the levels of plasma glucose, insulin, glucagon and cortisol were significantly different $(P<0.05)$ from the post-absorptive values and these changes were maintained throughout the feeding period (Fig. 2). Very transient increases were also observed in plasma insulin levels following the injection of $L-\left[1-{ }^{13} \mathrm{C}\right]$ leucine. During the measurements made in both the post-absorptive state and after $1 \mathrm{~h}$ of eating the 
(a)

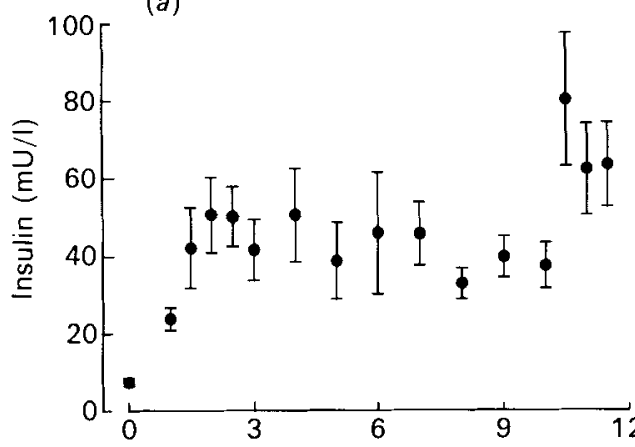

(b)
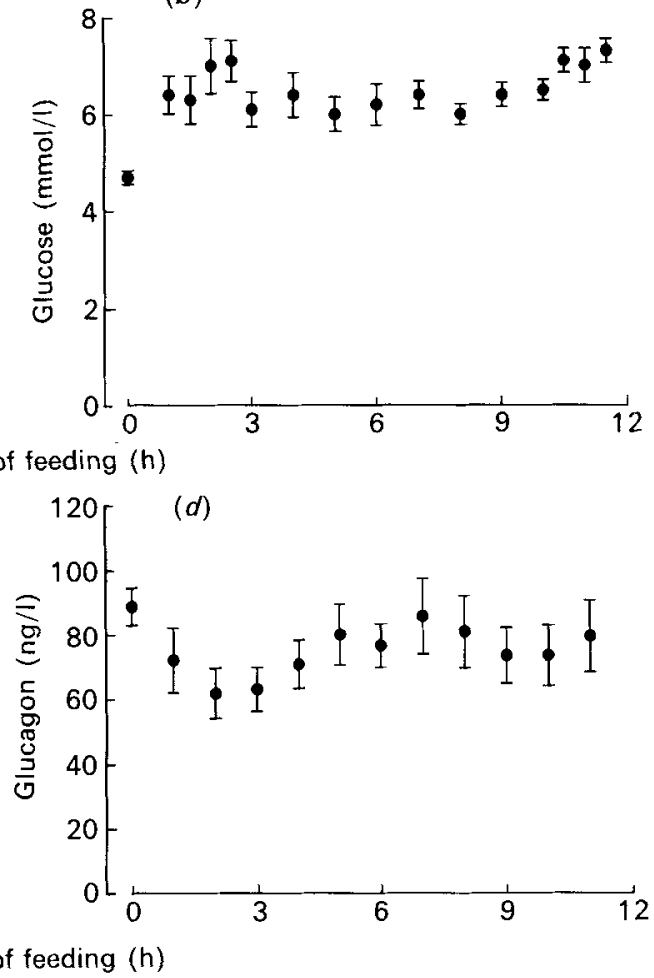

Fig. 2. Changes in plasma ( $a$ ) insulin, $(b)$ glucose, $(c)$ cortisol and (d) glucagon of healthy subjects from the postabsorptive state to $11 \mathrm{~h}$ of feeding. Points are means with their standard errors represented by vertical bars. For details of subjects and procedures, see pp. 118-119.

mean increase in insulin was less than $1 \mathrm{mU} / 1$. During the third measurement, made between the 10th and 11 th hours of eating, plasma insulin levels were $16 \mathrm{mU} / 1$ higher, an increase of $33 \%$ over the value at the beginning of the hour.

The observed increase in insulin includes both the response to the injected leucine and the response to the meal which was consumed at the beginning of the hour. In studies where somatostatin was infused to alter insulin levels we observed changes in whole-body carbohydrate and fat metabolism with increases in insulin levels of $30 \%$, but were unable to demonstrate changes in protein metabolism (McHardy et al. 1987; McNurlan et al. 1989). Moreover, in examining data from fifty measurements pooled from four other studies on muscle protein synthesis, it was not possible to demonstrate a correlation between insulin levels and rates of protein synthesis ( $P$. Essen, unpublished results). This inability to demonstrate a stimulatory effect of insulin on protein synthesis has also been reported by others including Pozefsky et al. (1969) and Pacy et al. (1989).

Expt 1 was performed with repeat measurements in each volunteer with the intention of minimizing any data scatter resulting from differences between individuals in the rate of muscle protein synthesis. It was, however, possible that scatter in the data, resulting in an inconclusive response to feeding, had been introduced because three measurements (six biopsies) in rapid succession might have been traumatic to the volunteer or to muscle metabolism. Therefore, Expt 2 was designed to examine the response of muscle protein synthesis to feeding when subjects only underwent one measurement each. The results of this experiment, shown in Table 2, indicate an increase of only about $10 \%$ in the group of 
Table 2. Expt 2. Rates of protein synthesis $\left(\mathrm{k}_{\mathrm{s}} ; \% / d\right)$ in quadriceps muscle from healthy subjects either fasted or fed for $10 \mathrm{~h}$ before measurement*

\begin{tabular}{cccc}
\hline Subject no. & Fasted & Subject no. & $10 \mathrm{~h}$ fed \\
\hline 1 & $1 \cdot 72$ & 7 & $2 \cdot 00$ \\
2 & $1 \cdot 25$ & 8 & 1.95 \\
3 & $2 \cdot 38$ & 9 & 1.68 \\
4 & $2 \cdot 22$ & 10 & $2 \cdot 37$ \\
5 & $2 \cdot 43$ & 11 & $2 \cdot 52$ \\
6 & $2 \cdot 60$ & 12 & $3 \cdot 50$ \\
Mean & $2 \cdot 10$ & & 2.34 \\
SEM & $0 \cdot 21$ & & 0.26 \\
\hline
\end{tabular}

* For details of subjects and procedures, see pp. 118-119.

subjects who ate for $10 \mathrm{~h}$ before measurement compared with the group of subjects who continued fasting for $10 \mathrm{~h}$. This difference is not statistically significant $(P>0.05)$.

The rates of muscle protein synthesis for both Expts 1 and 2 have been calculated assuming that the enrichment of the leucine on tRNA, the immediate precursor for protein synthesis, can be represented by that of KIC enrichment in plasma. The rationale for this assumption is that transamination of leucine to form KIC occurs within muscle tissue, so plasma KIC reflects intramuscular leucine enrichment (Matthews et al. 1982), with the added advantage that the time-course of changing enrichment can be monitored without multiple biopsies. However, with the flooding procedure there is little difference in enrichment between plasma leucine and plasma KIC or free leucine from muscle, as reported previously (Garlick et al. 1989). In the present study, if the enrichment of plasma leucine is used in the calculation of protein synthesis, the values are only slightly different and the statistical evaluation is not altered. In Expt 1 the values are 2.12 (SD 0.63), 2.20 (SD 0.46 ) and 2.87 (SD 0.88 ) for the post-absorptive, $1 \mathrm{~h}$-fed, and $10 \mathrm{~h}$-fed measurements respectively, compared with $2 \cdot 21,2 \cdot 15$ and 2.90 calculated for the respective groups with plasma KIC enrichment. The data in Expt 2 are also similar with plasma leucine enrichment or plasma KIC enrichment used for calculation: 1.91 (SD 0.47) v. $2 \cdot 10$ for the fasted subjects and 2.20 (SD 0.6 ) v. 2.34 for the fed subjects,

Since only one muscle biopsy was taken, the enrichment of free leucine within the muscle can be compared with plasma KIC only at the end of the incorporation period. Free leucine in muscle: plasma KIC ratio was 1.04 (SD 0.04) in the post-absorptive state, 1.07 (SD 0.04) after $1 \mathrm{~h}$ of feeding and 1.16 (SD 0.09) after $10 \mathrm{~h}$ of feeding. It is unlikely that the single values reflect precisely the relationship between muscle leucine and plasma KIC throughout the incorporation period, so it would be inappropriate to calculate synthesis rates with muscle free leucine. However, it is apparent that if the actual precursor was higher than plasma KIC for the measurement made after $10 \mathrm{~h}$ of feeding, as suggested by the muscle leucine: plasma leucine ratio of $1 \cdot 16$, then the synthesis rates would be somewhat lower than the values presented and the stimulation with feeding would also be somewhat smaller than that observed with KIC enrichment.

\section{DISCUSSION}

The development of the flooding technique for measuring rates of tissue protein synthesis over short periods of time made it possible to investigate acute responses of protein metabolism. Thus, studies in young growing animals demonstrated a $43 \%$ increase in the 
rate of skeletal muscle protein synthesis within $1 \mathrm{~h}$ of commencing feeding (Garlick et al. 1983). With the use of stable isotopes, the flooding technique can also be used in studies in man (Garlick et al. 1989) making it possible to investigate the normal, acute responses associated with the consumption of meals. We have, therefore, investigated the temporal changes in human muscle protein synthesis by sequential measurements in individuals measured after an overnight fast (i.e. post-absorptive) followed by measurements at $1 \mathrm{~h}$ and $10 \mathrm{~h}$ after they began eating.

Although demonstrable changes in plasma glucose, insulin, glucagon and cortisol occurred within the first hour (Fig. 2), there was no indication that the rate of protein synthesis in quadriceps muscle was altered (Table 1). Clearly, the rapidity of response to dietary nutrients was quite different in this group of adult subjects than that observed in young growing animals. There are two possibilities for this: either there is a species difference between rodents and man, or there is a difference in response between young, growing individuals and mature adults. Although the present study cannot differentiate between these two possibilities, studies reported by Baillie \& Garlick (1991) would suggest that muscle protein synthesis in adult rats is much less responsive to acute nutritional changes than in young growing animals and that the rate of protein degradation is the more important site of regulation in the adult. Wernerman et al. (1985) have also reported that muscle polyribosome configuration, another index of protein synthesis, was not altered by feeding in adult human subjects. This is consistent with the observation that degradation is very sensitive to nutrient intake when measurements are made on the whole body with $\mathrm{L}-\left[1{ }^{13} \mathrm{C}\right]$ leucine (see pp. 117-118). It seems likely, therefore, that the lack of response in muscle protein synthesis within the first $1-2.5 \mathrm{~h}$ of feeding was due to the adult, nongrowing stature of the subjects.

With continuation of eating for $10 \mathrm{~h}$, muscle protein synthesis was elevated in three of seven individuals. Although this was statistically significant by comparison with the values at $1 \mathrm{~h}$ of feeding $(P=0.05)$, it was not significant compared with the fasting values. In this experiment there is considerable variability in the rates of muscle protein synthesis and it is important to examine how much of the variability might be due to imprecision of measurement and how much might be due to differences amongst individuals. The precision of measurement was assessed previously by comparing estimates of protein synthesis in quadriceps muscles from both right and left legs. The data from that study indicate that the variations between individuals cannot be accounted for by the variability of measurement (McNurlan et al. 1991). Alternatively, the variability among the individuals of Expt 1 can be compared with the variability reported in other studies of muscle synthesis rate involving post-absorptive subjects. In Expt 1 the coefficient of variation (standard deviation/mean $\times 100$ ) was $30 \%$, comparable with that obtained in studies with continuous infusion (Rennie et al. 1982; Halliday et al. 1988; McNurlan et al. 1991) or with the flooding technique (Garlick et al. 1989; McNurlan et al. 1991; Essen et al. 1992). It would seem, therefore, that the variability in response among individuals arose from genuine differences rather than from imprecisions of measurement.

The observed stimulation was only $28 \%$ for the six paired measurements, a value considerably less than the $63 \%$ stimulation in muscle protein synthesis with feeding reported by Halliday et al. (1988). The study of Halliday et al. (1988) involved comparison of a group of volunteers who were fasted with a group of individuals that ate for $2 \mathrm{~h}$ before beginning an $8 \mathrm{~h}$ measurement of muscle protein synthesis by continuous infusion of $\mathrm{L}-\left[1-{ }^{13} \mathrm{C}\right]$ leucine. Consequently, each subject was only measured once. Each of the subjects in Expt 1, by contrast, was measured three times and it is possible that some of the subjects were not able to increase protein synthesis in response to eating because of stress responses arising from the multiple biopsies (six in total). 
Expt 2 was, therefore, undertaken to examine the response to feeding in subjects who were studied only once, either after $10 \mathrm{~h}$ of feeding or after $10 \mathrm{~h}$ of fasting (in addition to the overnight fast). The longer period of fasting than that in Expt 1 was included to eliminate the possibility that the different periods of fasting associated with the $90 \mathrm{~min}$ flooding and $6 \mathrm{~h}$ continuous infusion protocols might have influenced the result. The difference between the fed group (2.34 (SD 0.21)) and the fasted group (2.10 (SD 0.26)) was not statistically significant either by Student's $t$ test or by the non-parametric Mann-Whitney $\mathrm{U}$ test $(P>0.05)$. Thus, a lack of stimulation in muscle protein synthesis with feeding was observed even when the muscles had not been biopsied previously. In addition to the $t$ tests the difference between fasting and feeding can also be assessed in terms of the confidence limits. With the data of Expt 2, and taking $P<0.05$ as significant, the confidence interval is $-24 \%$ to $+47 \%$ (expressed as a percentage of the fasting value). Therefore, it is unlikely that a difference as great $(63 \%)$ as that reported by Halliday et al. (1988) would have been undetected.

There are some differences in protocol between Expt 2 and the study of Halliday et al. (1988). These include the length of fasting (somewhat longer in Expt 2) and the composition (cheese sandwiches $v$. milk-based) and frequency of feeding (hourly $v$. half-hourly). However, these differences are rather small and potentially more important differences in methodology between the two studies must also be considered.

The most obvious difference is the injection of a large amount of leucine: a possible effect of leucine on protein synthesis must be considered, particularly since the values for muscle protein synthesis in the post-absorptive state measured by the continuous-infusion technique are significantly lower $(1.1 \% / \mathrm{d}$; Halliday et al. 1988; McNurlan et al. 1991) than rates measured by the flooding technique. Previous experiments have shown that the incorporation of a labelled amino acid given in tracer amounts can be affected by the simultaneous administration of a flooding amount of leucine. However, the incorporation of some tracers increased and the incorporation of others actually decreased (McNurlan et al. 1979; Smith et al. 1991), and it would be incorrect to conclude that this necessarily represents altered protein synthesis. Since the interpretation from experiments with tracer amounts of labelled amino acids is ambiguous, we have used other methods to investigate the possibility that the flooding amount of leucine stimulated muscle protein synthesis.

When a flooding amount of $\mathrm{L}-\left[1-{ }^{13} \mathrm{C}\right]$ phenylalanine was used to measure protein synthesis in quadriceps muscle of post-absorptive volunteers the rates obtained were very similar to those obtained with $\mathrm{L}-\left[1-{ }^{13} \mathrm{C}\right]$ leucine (McNurlan et al. 1991). Investigations of the effect of large amounts of phenyalanine on protein synthesis both in vitro and in vivo have not provided evidence of stimulation (Li \& Jefferson, 1978; Garlick et al. 1980). Since it is unlikely that flooding amounts of both L-leucine and L-phenylalanine would stimulate protein synthesis to precisely the same level, the similar estimates of protein synthesis obtained with these two amino acids lends credence to the conclusion that leucine does not have a stimulatory effect on muscle protein synthesis in adult man. This conclusion is also supported by studies on limb amino acid balance which were unable to detect a stimulatory effect of leucine on phenylalanine balance or incorporation into protein (Hagenfeldt et al. 1980; Louard et al. 1990). Moreover, we have also used another method for estimating protein synthesis which does not rely on the interpretation of labelling kinetics. Changes in the aggregation of polyribosomes failed to indicate any stimulation of muscle protein synthesis by the amount of leucine used in flooding experiments (McNurlan et al. 1991).

If stimulation of muscle protein synthesis in adult volunteers by leucine is not likely then another possibility is a problem involving the estimate of precursor labelling with techniques involving tracer amounts of isotope. Such a condition might arise if, when postabsorptive and fed states are compared by continuous infusion of $\mathrm{L}-\left[1^{13} \mathrm{C}\right]$ leucine, there 
were to be a change in the source of amino acids for protein synthesis from those recycled from the degradation of protein in the post-absorptive state (relatively unlabelled) to amino acids from the plasma during feeding (relatively highly labelled). Nutrient deprivation has been shown previously to result in a change in the enrichment of TRNA relative to both intracellular and extracellular pools in cultured muscle cells (Low et al. 1984) and in pig muscle in vivo (Watt et al. 1989). Thus, the difference in labelling of protein between fasting and feeding might represent changes in precursor enrichment rather than changes in the rate of protein synthesis.

In conclusion, the results of the present study suggest that in adult man muscle protein synthesis was not readily stimulated by the intake of dietary nutrients despite rapid changes in plasma glucose, cortisol, glucagon and insulin. After $10 \mathrm{~h}$ of eating, muscle protein synthesis was elevated to a small degree $(10-30 \%)$ but the difference was of marginal significance in one experiment and not significant in the second. The two experiments can, however, be considered together. The observation of a small stimulation on two independent occasions tends to support the conclusion that feeding for $10 \mathrm{~h}$ results in a small increase in muscle protein synthesis.

The authors are most grateful to Mr A. G. Calder for his skilful mass spectrometry, to Mrs V. Buchan and Mr D. Brown for expert technical support and to Mrs E. Borstedt and Mrs A. Nilsson for their careful nursing assistance.

Financial assistance has been provided by Nestec, Ltd, Lausanne, Switzerland, the Swedish Medical Research Council (project no. 04210), the Maud and Birger Gustavsson Foundation, the County Council of Stockholm and the Scottish Hospital Endowments Research Trust.

\section{REFERENCES}

Baillie, A. G. S. \& Garlick, P. J. (1991). Attenuated responses of muscle protein synthesis to fasting and insulin in adult female rats. American Journal of Physiology 262 (Endocrin. Metab. 25), E1-E5.

Banauch, D., Brümmer, W., Ebeling, W., Metz, H., Rindfrey, H. \& Laung, H. (1975). Eine glucose-dehydrogenase für die glucose-bestimmung in körperflüssigkeiten (Glucose determination in body fuids by glucose dehydrogenase). Journal of Clinical Chemistry and Clinical Biochemistry 13, 101-107.

Bruce, A. C., McNurlan, M. A., McHardy, K. C., Broom, J., Buchanan, K. D., Calder, A. G., Milne, E., McGaw, B. A., Garlick, P. J. \& James, W. P. T. (1990). Nutrient oxidation patterns and protein metabolism in lean and obese subjects. International Journal of Obesity 14, 631-646.

Calder, A. G. \& Smith, A. (1988). Stable isotope ratio analysis of leucine and ketoisocaproic acid in blood plasma by gas chromatography/mass spectrometry. Use of the tertiary butyldimethylsilyl derivatives. Rapid Communications in Mass Spectrometry 2, 14-16.

Conway, J. M., Marable, N. L. \& Bodwell, C. E. (1988). Whole-body leucine and energy metabolism in adult women. European Journal of Clinical Nutrition 42, 661-669.

Dash, R. J., England, B. J., Midgley, J. A. R. \& Niswender, G. D. (1975). A specific, non-chromatographic radioimmunoassay for human plasma cortisol. Steroids 26, 647-661.

Eisentraut, A., Ohneda, A., Parada, E. \& Unger, R. H. (1968). Immunological discrimination between pancreatic and enteric glucagon-like immunoreactivity (GLI) in tissues and plasma. Diabetes 177, 321-322.

Essen, P., McNurlan, M. A., Wernerman, J., Milne, E., Vinnars, E. \& Garlick, P. J. (1992). Short-term starvation decreases skeletal muscle protein synthesis rate in man. Clinical Physiology 12, 287-299.

Ford, G. C., Cheng, K. N. \& Halliday, D. (1985). Analysis of $\left[1{ }^{13} \mathrm{C}\right]$ leucine and $\left[{ }^{13} \mathrm{C}\right] \mathrm{KIC}$ in plasma by capillary gas chromatography/mass spectrometry in protein turnover studies. Biomedical Mass Spectrometry 12 , $432-436$

Garlick, P. J., Fern, M. \& Preedy, V. R. (1983). The effect of insulin infusion and food intake on muscle protein synthesis in postabsorptive rats. Biochemical Journal 210, 669-676.

Garlick, P. J., McNurlan, M. A. \& Preedy, V. R. (1980). A rapid and convenient method for measuring the rate of protein synthesis in tissues by injection of $\left[{ }^{3} \mathrm{H}\right]$ phenylalanine. Biochemical Journal 192, 719-723.

Garlick, P. J., Wernerman, J., McNurlan, M. A., Essen, P., Lobley, G. E., Milne, E., Calder, A. G. \& Vinnars, E. (1989). Measurement of the rate of protein synthesis in muscle of postabsorptive young men by injection of a 'flooding dose' of $\left[1-^{13}\right.$ C $]$ leucine. Clinical Science $77,329-336$.

Hagenfeldt, L., Eriksson, S. \& Wahren, J. (1980). Influence of leucine on arterial concentrations and regional exchange of amino acids in healthy subjects. Clinical Science 59, 173-181. 
Halliday, D., Pacy, P. J., Cheng, K. N., Dworzak, F., Gibson, J. N. A. \& Rennie, M. J. (1988). Rate of protein synthesis in skeletal muscle of normal man and patients with muscular dystrophy: a reassessment. Clinical Science 74, 237-240.

Hoffer, L. J., Yang, R. D., Matthews, D. E., Bistrian, B. R., Bier, D. M. \& Young, V. R. (1985). Effects of meal consumption on whole body leucine and alanine kinetics in young adult man. British Journal of Nutrition $\mathbf{5 3}$, $31-38$.

Li, J. B. \& Jefferson, L. S. (1978). Influence of amino acid availability on protein turnover in perfused skeletal muscle. Biochimica et Biophysica Acta 544, 351-359.

Louard, R. J., Barrett, E. J. \& Gelfand, R. A. (1990). Effect of infused branched-chain amino acids on muscle and whole-body amino acid metabolism in man. Clinical Science 79, 457-466.

Low, R. B., Stirewalt, W. S., Rittling, S. R. \& Woodworth, R. C. (1984). Amino acid pools in cultured muscle cells. Journal of Cellular Biochemistry 25, 123-129.

McHardy, K. C., McNurlan, M. A., Fearns, L. M., Broom, J. \& Garlick, P. J. (1987). The use of somatostatin infusion to study the role of insulin in the regulation of nutrient oxidation in man. Endocrinology 112, Suppl., $79 \mathrm{~A}$.

MacKenzie, S. L. \& Tenaschuk, D. (1974). Gas-liquid chromatography of N-heptafluorobutyryl isobutyryl esters of amino acids. Journal of Chromatography 97, 19-24.

McNurlan, M. A., Essen, P., Heys, S. D., Buchan, V., Garlick, P. J. \& Wernerman, J. (1991). Measurement of protein synthesis in human skeletal muscle: Further investigation of the flooding technique. Clinical Science 81, $557-564$

McNurlan, M. A., Essen, P., Vinnars, E., Garlick, P. J. \& Wermerman, J. (1990). Delayed response to feeding on protein synthesis in human skeletal muscle measured by the flooding dose technique. Clinical Nutrition $\mathbf{9}$, Special Suppl., 12.

McNurlan, M. A., McHardy, K. C., Broom, J., Calder, A. G., Milne, E. \& Garlick, P. J. (1989). Responses of whole-body protein turnover in man to feeding: lack of dependence on insulin. FEBS Journal 3, A1259.

McNurlan, M. A., Tomkins, A. M. \& Garlick, P. J. (1979). The effect of starvation on the rate of protein synthesis in rat liver and small intestine. Biochemical Journal 178, 373-379.

Matthews, D. E., Schwartz, H. P., Young, R. D., Motil, K. J. \& Young, V. R. (1982). Relationship of plasma leucine and $\alpha$ ketoisocaproate during a L-I-[ $\left[{ }^{13} \mathrm{C}\right]$ leucine infusion in man: a method for measuring human intracellular leucine tracer enrichment. Metabolism 31, 1105-1112.

Melville, S., McNurlan, M. A., McHardy, K. C., Broom, J., Milne, E., Calder, A. G. \& Garlick, P. J. (1989). The role of degradation in the acute control of protein balance in adult man: Failure of feeding to stimulate protein synthesis as assessed by $\mathrm{L}-\left[1-{ }^{13} \mathrm{C}\right]$ leucine infusion. Metabolism 38, 248-255.

Midgley, A. R., Rabau. R. W. \& Niswender, G. D. (1969). Radioimmunoassays employing double antibody techniques. Acta Endocrinologica 142, Suppl., 247-254.

Motil, K. J., Bier, D. M., Matthews, D. E., Burke, J. F. \& Young, V. R. (1981 a). Whole body leucine and lysine metabolism studied with $\left[1-{ }^{13} \mathrm{C}\right]$ leucine and $\left(\alpha^{15} \mathrm{~N}\right]$ lysine: Response in healthy young men given excess energy intake. Metabolism 30, 783-791.

Motil, K. J., Matthews, D. E., Bier, D. M., Burke, J. G., Munro, H. N. \& Young, V. R. (1981b). Whole body leucine and lysine metabolism: Response to dietary protein intake in young men. American Journal of Physiology 240, E712-E721.

Pacy, P. J., Nair, K. S., Ford, C. \& Halliday, D. (1989). Failure of insulin infusion to stimulate fractional muscle protein synthesis in type 1 diabetic patients. Diabetes $38,618-624$.

Pozefsky, T., Felig, P., Tobin, J. D., Soeldner, J. S. \& Cahill, J. G. F. (1969). Amino acid balance across tissues of the forearm in postabsorptive man, effects of insulin at two dose levels. Journal of Clinical Investigation 48, 2273-2282.

Read, W. W., Read, M., Rennie, M. J., Griggs, R. C. \& Halliday, D. (1984). Preparation of $\mathrm{CO}_{2}$ from blood and protein-bound amino acid carboxyl groups for quantitation of ${ }^{13} \mathrm{C}$-isotope enrichments. Biomedical Mass Spectrometry 11, 348-352.

Rennie, M. J., Edwards, R. H. T., Halliday, D., Matthews, D. E., Wolman, S. L. \& Millward, D. J. (1982). Muscle protein synthesis measured by stable isotope techniques in man: The effects of feeding and fasting. Clinical Science 63, 519-523.

Smith, K., Barua, J. M., Watt, P. W., Scrimgeour, C. M., Rickhuss, P. K. \& Rennie, M. J. (1991). Preliminary evidence of artefactually high values of muscle protein synthesis obtained by the flooding dose technique compared with the constant infusion method. Clinical Nutrition 10, 7.

Watt, P. W., Stenhouse, M. G., Corbett, M. E. \& Rennie, M. J. (1989). t-RNA charging in pig muscle measured by $\left[1^{13} \mathrm{C}\right]$ leucine during fasting and infusion of amino acids. Clinical Nutrition $8,47$.

Wernerman, J., von der Decken, A. \& Vinnars, E. (1985). The diurnal pattern of protein synthesis in human skeletal muscle. Clinical Nutrition 4, 203-205.

Young, V. R., Gucalp, C., Rand, W. M., Matthews, D. E. \& Bier, D. M. (1987). Leucine kinetics during three weeks at submaintenance-to-maintenance intakes of leucine in men: Adaptation and accommodation. Human Nutrition: Clinical Nutrition 41C, $1-18$. 